\title{
Health properties of Yerba Mate
}

\author{
Piotr Lutomski ${ }^{1, A-D \oplus}$, Małgorzata Goździewska' ${ }^{1, A, D-E \oplus}$, Magdalena Florek-Łuszczki ${ }^{1, E-F \oplus}$ \\ ${ }^{1}$ Department of Medical Anthropology, Institute of Rural Health, Lublin, Poland \\ A - Research concept and design, B - Collection and/or assembly of data, C - Data analysis and interpretation, \\ $D$ - Writing the article, E - Critical revision of the article, F- Final approval of article
}

Lutomski P, Goździewska M, Florek-Łuszczki M. Health properties of Yerba Mate. Ann Agric Environ Med. 2020 ; $27(2)$ : $310-313$. doi: 10.26444/aaem/119994

\begin{abstract}
Introduction. Yerba Mate, also called Paraguay tea, is obtained from the dried leaves (approximately 95\%) and stems (about 5\%) of the evergreen shrub-tree llex paraguariensis. Each year, the consumption of yerba mate becomes increasingly popular in North America and Europe. The fashion for Paraguay tea has also reached Poland. During the period 2012 - 2018 , as much as an 8-fold increase has been observed in the import of this raw material to our country.

Objective. The aim of the study is analysis of the present state of knowledge concerning the health effects of Yerba Mate, based on selected scientific literature.

Dicussion. The consumption of yerba mate may exert a beneficial effect on human health and its consumption is recommended in the treatment of obesity and while practicing sports. Nevertheless, it should be remembered that a very high consumption of the tea, especially when very hot, may increase the risk of occurrence of cancer, which has not been unequivocally confirmed by scientific studies to-date.

Conclusions. It has been confirmed that this beverage shows a number of beneficial health effects, including: a protective effect on liver cells, stimulation of the central nervous system, anti-inflammatory effect, as well as a positive effect on the cardiovascular system.
\end{abstract}

\section{Keywords}

tea, Yerba mate, medicinal effects (health implications), Ilex paraguariensis

\section{INTRODUCTION}

Yerba Mate, also called Paraguay tea, is brewed from the dried, crushed leaves (constituting about 95\%) and stems (approximately 5\%) of Ilex paraguariensis A.St.-Hilaire tree [1]. This is a plant native to South America which grows primarily in northern Argentina (Corrientes, Misiones), Paraguay, Uruguay and southern Brazil (Rio Grande do Sul, Santa Catarina, Paraná and Mato Grosso do Sul). It is relatively difficult to cultivate Ilex paraguariensis in other parts of the world, and to-date, attempts to cultivate this plant in regions with a similar climate, e.g. North America, Asia, Africa, have been unsuccessful. Therefore, the main crops come primarily from wild growing trees, although in recent years an increase has taken place in land areas under controlled cultivation in South America [2].

Paraguay tea was discovered by Guarani Indians, living at one time in the basin of the Paraguay River. Inhabitants of this region regarded the Paraguayan holly plant as a gift from 'Mother Earth' [1]. At present, the brew, called 'mate' in Spanish-speaking countries, or 'chimarrão' in Brazil, is prepared by the partial filling of a gourd with dried leaves and hot water at the temperature of $70-80^{\circ} \mathrm{C}$. The content of the gourd may be added to several times with warm or cold water (tereré). In order that the crushed leaves, fine stems and dust do not get into the mouth, 'bombilla' are used, i.e. drinking straws with a filter for drinking the beverage. Dried yerba mate is appreciated worldwide due to its taste, aroma, stimulatory, health-promoting and nutritional attributes [3].

In South America, the Paraguayan holly plant is among the most commercially cultivated plants. Approximately $30 \%$ of

Address for correspondence: Piotr Lutomski, Department of Medical Anthropology, Institute of Rural Health, Lublin, Poland

E-mail: lutomski.piotr@imw.lublin.pl

Received: 11.07.2019; accepted: 25.03.2020; first published:03.04.2020 the population of this continent drink more than one litre of the brew daily [4]. In 2002 in Argentina, the National Yerba Mate Institute was founded (Instituto Nacional de la Yerba Mate), which initiates and finances studies of the properties of this plant. Yerba mate enjoys great popularity in Paraguay and Uruguay, where it is consumed even on the way to work or during everyday walks. In Argentina, approximately $5 \mathrm{~kg}$ of dried leaves per capita are consumed annually, while in Uruguay - about $10 \mathrm{~kg}$ [5].

The consumption of Yerba Mate tea has become increasingly popular in North America and Europe [6]. The fashion for Paraguay tea has also reached Poland. From 2012-2018, as much as an 8-fold increase has taken place in the import of this dried plant to our country, and in 2016, approximately 150 tons of dried yerba mate were imported, $65 \%$ of which came from Argentina [7]. The beverage is promoted in the media, and imbibed by celebrities and dieticians who emphasize its pro-health qualities. The dried leaves of Yerba Mate contain about 200 chemical substances, including: minerals, xanthines, flavonoids, anthocyanins and procyanidins, phenolic acids, rutins and saponins [Tab.1]. Mate is applied as a medicine for fatigue, anxiety, supporting metabolism and stimulation of the nervous system [1]. Its consumption may be the source of many valuable mineral components

Effect of Yerba Mate on the state of health. In recent years, many studies have been conducted analyzing the effect of the consumption of Ilex paraguariensis on the state of health of humans and animals. In 2011, observations were performed in a group of males and females taking Yerba Mate supplements in the form of tablets ( 3 tablets per each meal, total 3 times a day $-3 \mathrm{~g} /$ day). After 12 weeks of administration, a reduction of body mass of the examined persons was observed, and a decrease in the waist-to-hip ratio. Therefore, the high 
Table 1. Main bioactive compounds found in Yerba Mate and their health benefits [8].DCQ - Dicaffeoylquinic acid

\begin{tabular}{|c|c|c|c|}
\hline Compounds & $\begin{array}{c}\text { Amount } \\
\text { (\% of dry weight) }\end{array}$ & Known health benefits & References \\
\hline Caffeoyl derivatives & 10.000 & & Filip et al., 2001 [9]. \\
\hline Chlorogenic acid & 2.800 & $\begin{array}{l}\text { Antioxidant, antimicrobial, } \\
\text { antidiabetic, analgesic }\end{array}$ & Filip et al., 2001 [9] \\
\hline Caffeic acid & 0.023 & Antioxidant & $\begin{array}{l}\text { Filip et al., } 2000[10] ; 2001 \text { [9]; } \\
\text { Heck and de Mejia, } 2007 \text { [ 6] }\end{array}$ \\
\hline 3,4-DCQ* & 0.855 & Anticancer, antioxidant & (Filip et al. 2001 [9]; Arbiser et al., 2005 [11] \\
\hline 3,5-DCQ & 3.040 & Anticancer, antioxidant & (Filip et al., 2001 [9] Arbiser et al., 2005 [11] \\
\hline 4,5-DCQ & 2.890 & & (Filip et al., 2001 [9]. \\
\hline Saponins & 5 to 10 & $\begin{array}{l}\text { Anticancer, Anti-inflammation, } \\
\text { antiparasitic }\end{array}$ & $\begin{array}{l}\text { Taketa et al., } 2004 \text { [12]; Puangpraphant et al., } \\
2011 \text { [13] }\end{array}$ \\
\hline Xanthines & Caffeine 1 to $2 \%$ & $\begin{array}{l}\text { Anticarcinogenic, antiobesity, } \\
\text { antioxidant, } \\
\text { diuretic, stimulant, vasodilato }\end{array}$ & $\begin{array}{l}\text { Ito et al. } 1997 \text { [14]; Heck and de Mejia, } \\
2007 \text { [6] }\end{array}$ \\
\hline Theobromine & 0.3 to $0.9 \%$ & Stimulant, diuretic & $\begin{array}{l}\text { Ito et al., } 1997 \text { [14]; Heck and de Mejia, } 2007 \\
\text { [6] }\end{array}$ \\
\hline Theophylline & 0 to trace & Stimulant, vasodilator & $\begin{array}{l}\text { Ito et al., } 1997 \text { 14; Heck and de Mejia, } 2007 \\
\text { [6] }\end{array}$ \\
\hline Rutin & 0.060 & $\begin{array}{l}\text { Antioxidant, lipoxygenase-inhibitor, } \\
\text { anticancer, anti-tumor, anti-ulcer }\end{array}$ & $\begin{array}{l}\text { Arbiser et al., } 2005 \text { [11]; Heck and de Mejia, } \\
2007 \text { [6] }\end{array}$ \\
\hline Quercetin & 0.0031 & $\begin{array}{l}\text { Anticancer, anti-inflammation, } \\
\text { antimicrobial }\end{array}$ & $\begin{array}{l}\text { Rauha et al., } 2000[15] \text {; Arbiser et al., } 2005 \\
\text { [11]; Puang praphant and de Mejia, } 2009 \text { [16] }\end{array}$ \\
\hline Kaempferol & 0.0012 & Anti-inflammation, antimicrobial & $\begin{array}{l}\text { Rauha et al., } 2000 \text { [15]; Puangpraphant } \\
\text { and de Mejia, } 2009 \text { [16] }\end{array}$ \\
\hline
\end{tabular}

effectiveness of Paraguay tea was suggested in the treatment of obesity $[17,18]$. Studies conducted on mice indicated that a long-term supplementation of Yerba Mate may be beneficial not only in reducing obesity, but also insulin resistance, dyslipidaemia and hepatic steatosis [19, 20, 21, 22].

Other studies conducted in a group of males and females confirmed that a one-gram capsule containing Yerba Mate taken before physical exercises of moderate intensity may increase fat burning by $24 \%$, and contribute to the improvement of sports outcomes without negatively affecting maximal exercise performance [23].

While analyzing the content of fatty acids in brews from Yerba Mate mixtures, a considerable presence of linoleic acid and alpha-linolenic acid was found. Their presence in a fresh brew was approx. $250 \mathrm{ug} / \mathrm{mL}$ for linoleic acid, and $600 \mathrm{ug} /$ $\mathrm{mL}$ for alpha-linolenic acid [24]. Thus, the consumption of Yerba Mate brew may provide the body with alpha-linolenic and linolenic acids, which are indispensable for an adequately composed diet. For persons who regularly consume Yerba Mate, this may be an important source of supplementation of polyunsaturated fatty acids.

A study conducted by Puangpraphant et al. [25] in 2011 confirmed that the leaves of the Paraguayan holly plant possess both anti-cancer and anti-inflammatory properties. The results show that derivatives of caffeoylquinic acid (CQA) effectively cure colorectal cancer, and may reduce inflammatory conditions in other diseases. Yerba Mate contains saponins, which are natural compounds showing anti-inflammatory properties. In addition, this beverage contains small amounts of vitamins $\mathrm{C}$ and $\mathrm{E}$, selenium and zinc [6].

Yerba Mate may also prevent infections caused by bacteria, parasites and fungi. It was confirmed that a high dose of the extract deactivated $E$. Coli bacteria which cause the symptoms of food poisoning, such as stomach cramps and diarrhea [26, 27]. Compounds present in Ilexparaguariensis A.St.-Hil., may also prevent the growth of Malassezia furfur, a fungus responsible for skin exfoliation, dandruff, seborrheic dermatitis and skin rashes. Traditional treatment of this fungal infection with the use of relatively toxic drugs is longlasting and costly. Filip et al. [28] observed that the aqueous extract of Yerba Mate $(1,000,000 \mu \mathrm{g} / \mathrm{mL})$ possesses inhibitory activity against Malassezia furfur. This anti-malassezial activity was equivalent to $2.7 \mu \mathrm{g} / \mathrm{mL}$ of ketoconazole. They suggest the topical use of Ilex paraguariensis extract as an alternative anti-fungal agent [28]. It was proved that many of the saponins found in the species of Paraguayan holly plant (triterpenoid saponins with ursolic and oleanolic moieties) also show anti囚inflammatory and hypocholesterolemic properties [6]. In the study by Ronco et al. in a population of Uruguayan women, a protective effect of mate was observed, and the relationship was confirmed between a high consumption (more than one litre) of the brew, and a lower risk of the occurrence of breast cancer [29].

Yerba Mate has gained great popularity, not only for healthpromoting but also for stimulatory reasons, and has become a substitute for coffee. Two hundred millilitres of the brew contains approximately $71.8 \mathrm{mg}$ of caffeine, whereas the same amount of cappuccino coffee - $86.8 \mathrm{mg}$ [30]. Yerba Mate is usually consumed more often than coffee, considering the possibility of repeated infusion (even up to 7 times), without any significant loss of taste and nutritional values [31].

Caffeine, apart from its stimulatory effect and elimination of the feeling of fatigue, may also improve short-term memory, as well as alertness and reaction time, which was confirmed in people consuming from 37.5 - $450 \mathrm{mg}$. of caffeine daily. Regular consumers of Yerba Mate admit that the brew gives 
them energy, while at the same time, not causing nervousness which sometimes occurs after the consumption of coffee [32]. In addition, research carried out on rats demonstrated that Yerba Mate is safe for bone health, despite the high content of caffeine that has a negative impact on bone mineral density [33]. However, it should be remembered that an excessive amount of caffeine may cause headache, migraine and high blood pressure in some people, especially in pregnant women, who should limit its consumption due to the risk of miscarriage and low birth weight of a baby [32].

The most beneficial method of imbibing Yerba Mate seems to be a cold brew, which supplies the highest dose of unaltered polyunsaturated fatty acids. This method also reduces exposure of the gastrointestinal tract to high temperature, thus decreasing the risk of contracting cancer [24].

Yerba Mate possesses a confirmed pro-health effect on the human body provided that it is consumed in moderation. It should be emphasized that polycyclic aromatic hydrocarbons (PAH), which the Paraguay tea contains, are known carcinogenic factors which also occur in tobacco smoke and grilled meat [6]. A study conducted in a group of Uruguayan males confirmed the relationship between the consumption of Yerba Mate (more than 2.5 litre daily) and an increased risk of oesophageal cancer $[34,35]$. Observations carried out in South America proved that there is a relationship between an increased risk of cancer and a considerable amount of the brew consumed. It was confirmed that the consumption of more than a litre of Yerba Mate daily may considerably increase the risk of the occurrence of cancer of the neck and head. Moreover, the consumption of a very hot beverage may contribute to the development of cancer of the mouth. Nevertheless, it should be taken into account that many populations analyzed simultaneously also consumed alcohol and tobacco products, which might have had an effect of the results obtained $[36,37,38]$.

Another study was carried out exposing rats to drinking Yerba Mate prepared with hot water for the remainder of their lives. Histological examination of the upper aerotract, pancreas, bladder, stomach, oesophagus, duodenum and kidney was conducted 5 months into the experiment. Significant differences were found, especially in the incidence of tracheitis and bronchiolitis, between the groups that drank Yerba Mate and the controls that drank only water. This study indicated that continuous consumption of Paraguay tea during a large part of life could affect the upper aerodigestive tract, but did not cause tumours in the oesophagus, oral cavity, bladder or kidneys [35].

\section{CONCLUSIONS}

Consumption of Yerba Mate may exert a beneficial effect on the human state of health. It was confirmed that the beverage shows a number of beneficial health effects, including, among others, protective effect on liver cells, stimulation of the central nervous system, anti-inflammatory effect, and beneficial effect on the cardiovascular system. The consumption of Paraguay tea is also recommended in the treatment of obesity, and while practicing sports. However, it should be kept in mind that a very high consumption of Yerba Mate, especially at a high temperature, may increase the risk of the development of cancer which, however, has not been unequivocally proved $[37,38,39,40]$.
Although Yerba Mate has been consumed for ages, it has been investigated from the scientific point of view only during the last 2 decades. Considering the growing interest in its consumption worldwide, it seems justifiable to conduct a larger number of studies analyzing the effect of Yerba Mate on human health [41]. Precise research should be carried out which would present the effects of consumption of the beverage, while at the same time eliminating the effect of other factors (i.e. contaminations introduced during the industrial processing of the leaves, use of stimulants, for example: alcohol and tobacco by study participants), which could interfere with the process of the analyses performed.

\section{REFERENCES}

1. Florczak J, Karmańska A, Wędzisz A, Brożek E. Skład chemiczny suszu różnego gatunku yerba mate. Bromat Chem Toksykol. 2011; 4: $1105-1110$.

2. Fernandez Baez CD, Ruzickova G. Consumption of Yerba Mate. (Ilex paraguariensis L.) in the Czech Republic. Mendel University in Brno, Faculty of Agronomy, Departement of Crop Science, Breeding and Plant Medicine, Brno 2010.

3. Markowicz Bastos DH, Moura de Oliveira D, Teixeira Matsumoto RL, Carvalho P, Ribeiro ML. Yerba maté: Pharmacological Properties, Research and Biotechnology. Medicinal and Aromatic Plant Science and Biotechnology, Global Science Books 2007.

4. Filip R, Ferraro G. Researching on new species of "Mate": Ilex brevicuspis Phytochemical and pharmacology study. Eur J Nutrit. 2003; 42(1): 50-54.

5. Lewan T, Associated Press Writer, The Bitter Tea South Americans Love to Drink, APWSTM. international. http://web.mit.edu/rjbarbal/ Te... (access: 2018.11.01).

6. Heck CI, de Mejia EG. Yerba Mate Tea (Ilex paraguariensis): a comprehensive review on chemistry, health implications, and technological considerations. J Food Sci. 2007 Nov; 72(9): R138-51.

7. Dmowski P, Post L. Wpływ krotności parzenia na właściwości przeciwutleniające naparów yerba mate. Zeszyty Naukowe Akademii Morskiej w Gdyni 2018; 104: 9-18.

8. Burris PK, Harte FM, Davidson MP, Neal Stewart CN, Zivanovic S. Composition and bioactive properties of yerba (Ilex paraguariensis A. St.-Hil.). J Agric Res. 2012; 72(2).

9. Filip R, Lopez P, Giberti G, Coussio J, Ferraro G. Phenolic compounds in seven South American Ilex species. Fitoterapia 2001; 72: 774-778.

10. Filip R, Lotito SB, Ferraro G, Fraga CG. Antioxidant activity of Ilex paraguariensis and related species. Nutri Res. 2000; 20: 1437-1446.

11. Arbiser JL, Li XC, Hossain CF, Nagle DG, Smith DM, Miller P, et al. Naturally occurring proteasome inhibitors from mate tea (Ilex paraguayensis) serve as models for topical proteasome inhibitors. J Invest Dermatol. 2005; 125: 207-212.

12. Taketa ATC, Gnoatto SCB, Gosmann G, Pires VS, Schenkel EP, Guillaume D. Triterpenoids from Brazilian Ilex species and their in vitro antitrypanosomal activity. J Natural Prod. 2004b; 67: 1697-1700.

13. Puangpraphant S, Berhow MA, de Mejia EG. Mate (Ilex paraguariensis St Hilaire) saponins induce caspase-3-dependent apoptosis in human colon cancer cells in vitro. Food Chemistry 2011; 125: 1171-1178.

14. Ito E, Crozier A, Ashihara H. Theophylline metabolism in higher plants. Biochim Biophys Acta 1997; 1336: 323-330.

15. Rauha JP, Remes S, Heinonen M, Hopia A, Kahkonen M, Kujala T, et al. Antimicrobial effects of Finnish plant extracts containing flavonoids and other phenolic compounds. Int J Food Microbiol. 2000; 56: 3-12.

16. Puangpraphant S, de Mejia EG. Saponins in yerba mate tea (Ilex paraguariensis A. St.-Hil) and quercetin synergistically inhibit iNOS and COX-2 in lipopolysaccharide-induced macrophages through NFKB pathways. J Agric Food Chem. 2009; 57: 8873-8883.

17. Sun-Young Kim, Mi-Ra Oh, Min-Gul Kim, Han-Jeoung Chae, SooWan Chae. Anti-obesity effects of Yerba Mate (Ilex Paraguariensis): a randomized, double-blind, placebo-controlled clinical trial. BMC ComplementAltern Med. 2015; 15: 338. DOI 10.1186/s12906-015-0859-1

18. Andersen T, Fogh J. Weight loss and delayed gastric emptying following a South American herbal preparation in overweight patients. J Hum Nutr Diet. 2001; 14: 243-50. 
19. Myung-Sook Choi, Hyo Jin Park, Sang Ryong Kim, Do Yeon Kim Un Ju Jung. Long-Term Dietary Supplementation with Yerba Mate Ameliorates Diet-Induced Obesity and Metabolic Disorders in Mice by Regulating Energy Expenditure and Lipid Metabolism. J Med Food. 2017; 20(12): 1.

20. Young-Rye Kang, Hak-Yong Lee, Jung-Hoon Kim, Dea-In Moon, MinYoung Seo, Sang-Hoon Park, et al. Anti-obesity and anti-diabetic effects of Yerba Mate (Ilex paraguariensis) in C57BL/6J mice fed a high-fat diet. Lab Anim Res. 2012 Mar; 28(1): 23-29. doi: 10.5625/lar.2012.28.1.23.

21. de Oliveira E, Lima NS, Conceição EPS, Peixoto-Silva N, Moura EG, Lisboa PC. Treatment with Ilex paraguariensis (yerba mate) aqueous solution prevents hepatic redox imbalance, elevated triglycerides, and microsteatosis in overweight adult rats that were precociously weaned. Braz J Med Biol Res. 2018; 51(6): e7342.

22. Gambero A, Ribeiro ML. The positive effects of yerba maté (Ilex paraguariensis) in obesity. Nutrients. 2015; 7(2): 730-50. doi:10.3390/ nu7020730.

23. Alkhatib A. Yerba Maté (Illex Paraguariensis) ingestion augments fat oxidation and energy expenditure during exercise at various submaximal intensities. Nutr Metab (Lond). 2014; 11: 42.. doi: [10.1186/1743-7075-11-42].

24. Maciejewska D, Łukomska A, Jakubczyk K, Baranowska-Bosiacka I, Stachowska E, Chlubek D, et al. The content of linoleic and alphalinolenic acid in different types of Yerba Mate, depending on country of origin and the conditions of the infusion. Pom J Life Sci. 2015; 61(1): 90-93.

25. Puangpraphant S, Berhow MA, Vermillion K, Potts G, Gonzalez de Mejia E, Dicaffeoylquinic acids in Yerba mate (Ilex paraguariensis St. Hilaire) inhibit NF- $\kappa \mathrm{B}$ nucleus translocation in macrophages and induce apoptosis by activating caspases- 8 and -3 in human colon cancer cells. Mol Nutr Food Res. 2011 Oct; 55(10): 1509-22. doi: 10.1002/ mnfr.201100128. Epub 2011 Jun 8.

26. Burris KP, Davidson PM, Stewart CN Jr, Zivanovic S, Harte FM. Aqueous extracts of yerba mate (Ilex paraguariensis) as a natural antimicrobial against Escherichia coli O157:H7 in a microbiological medium and pH 6.0 apple juice. J Food Prot. 2012 Apr; 75(4): 753-7. doi: 10.4315/0362-028X.JFP-11-214.

27. Burris KP, Davidson PM, Stewart CN Jr, Harte FM. Antimicrobial activity of Yerba Mate (Ilex paraguariensis) aqueous extracts against Escherichia coli O157:H7 and Staphylococcus aureus. J Food Sci. 2011 Aug; 76(6): M456-62. doi: 10.1111/j.1750-3841.2011.02255.x. Epub 2011 Jul 5.
28. Filip R, Davicino R, Anesini C. Antifungal activity of the aqueous extract of Ilex paraguariensis against Malassezia furfur. Phytother Res. 2010 May; 24(5): 715-9. doi: 10.1002/ptr.3004.

29. L Ronco A, Vazquez A, Ronco A, De Stefani E, Mendoza B, Vazquez A, et al. Mate and Tea Intake, Dietary Antioxidants and Risk of Breast Cancer: a Case-Control Study. Asian Pac J Cancer Prev. 2016; 17(6): 2923-2933.

30. https://www.caffeineinformer.c... (access: 2018.11.01).

31. Pawlak-Lemańska K, Zarzyka O, Gliszczyńska-Świgło A, Tyrakowska B. Yerba Mate, Black and Green Tea Infusions: Comparison of Their Alkaloid Content and Antioxidant Activity. Towaroznawcze Problemy Jakości 2016; 1: 105-114.

32. Ruxton $\mathrm{CH}$ S. The impact of caffeine on mood, cognitive function, performance and hydration: a review of benefits and risks. The Author Journal compilation, British Nutrition Foundation Nutrition Bulletin 2008; 33: 15-25.

33. Brun LR, Brance ML, Lombarte M, et al. Effects of Yerba Mate (IIex paraguariensis) on Histomorphometry, Biomechanics, and Densitometry on Bones in the Rat. Calcif Tissue Int. 2015; 97: 527. https://doi.org/10.1007/s00223...

34. De Stefani E, Muñoz N, Estève J, Vasallo A, Victora CG, Teuchmann S. Mate drinking, alcohol, tobacco, diet, and esophageal cancer in Uruguay. Cancer Res. 1990 Jan 15; 50(2): 426-31.

35. Loria D, Barrios E, Zanetti R. Cancer and yerba mate consumption: a review of possible associations. Rev Panam Salud Publica. 2009 Jun; 25(6): 530-9.

36. Szymańska K, Matos E, Hung RJ, Wünsch-Filho V, Eluf-Neto J, Menezes A, et al. Drinking of maté and the risk of cancers of the upper aerodigestive tract in Latin America: a case-control study. Cancer Causes Control. 2010; 21: 1799. https://doi.org/10.1007/s10552...

37. Goldenberg D, Golz A, Joachims HZ. The beverage maté: a risk factor for cancer of the head and neck. Head Neck. 2003 Jul; 25(7): 595-601.

38. Goldenberg D, Lee J, Koch WM, Kim MM, Trink B, Sidransky D, et al. Habitual risk factors for head and neck cancer. Otolaryngol Head Neck Surg. 2004; 131(6): 986-93. DOI: 10.1016/j.otohns.2004.02.035.

39. Sewram V, De Stefani E, Brennan P, Boffetta P. Mate consumption and the risk of squamous cell esophageal cancer in Uruguay. Cancer Epidemiol Biomarkers Prev. 2003; 12: 508-13.

40. Riachi LG, De Maria CAB. Yerba mate: An overview of physiological effects in humans, J Funct Foods. 2017; 38, 308-320.

41. Cardozo Junior EL, Morand C. Interest of mate (Ilex paraguariensis A. St.-Hil.) as a new natural functional food to preserve human cardiovascular health - A review. J Funct Foods. 2016; 21: 440-454. 